\title{
Evaluation of Gross Regional Product Waste Intensity in Context of the SDGs Achievement Progress Assessment
}

\author{
Iryna Dzhygyrey
}

Department of Mathematical Methods of Systems Analysis, Igor Sikorsky Kyiv Polytechnic Institute, UKRAINE, Kyiv, Peremogy av. 37, E-mail: lab.mes@kpi.ua

Abstract - GRP waste intensity assessment is presented for 2015-2019 data years based on GRP values at constant 2015 prices and waste generation by regions from the economic activity of enterprises and organizations. GRP waste intensity indicator values for regions of Ukraine are presented compared to the 2015 base year considering the 2030 SDG 12 benchmark.

Keywords - gross regional product, progress assessment, region, sustainable consumption and production, sustainable development goals, waste intensity.

\section{Introduction}

In 2015, the UN General Assembly adopted the 2030 Agenda for Sustainable Development which includes 17 Sustainable Development Goals (SDGs) to be achieved by 2030. The Ukrainian national SDGs system consists of 86 national SDGs targets with benchmarks and 183 national SDGs monitoring indicators [1]. The economic dimension of SDGs covers of four goals, one of which is «Ensure sustainable consumption and production patterns» or SDG 12 «Sustainable consumption and production» for short.

«Reduce resource consumption of the economy» is one of four national SDG 12 targets. Resource intensity of GDP indicator (ratio of consumed volumes of natural resources, waste generated, and pollutant emissions to GDP, \% to 2015 level) represents the evaluation of progress achievement for this target of the national SDG 12. Five components, GDP energy intensity, GDP material intensity, GDP carbon intensity, GDP water intensity, and GDP waste intensity, express the national indicator of resource intensity of GDP. The 2020 benchmark is established at $90.0 \%$, the 2025 benchmark is $80.0 \%$, and the 2030 benchmark is $60.0 \%$ for all five components. GDP waste intensity is presented in Table 1 as changes to the 2015 level (data of the State Statistics Service of Ukraine as of May 2021, data exclude the temporarily occupied territory of the Autonomous Republic of Crimea, the city of Sevastopol, and a part of temporarily occupied territories in the Donetsk and Luhansk regions, the 2020 data will be available in January of 2022).

Table 1

GDP (2011 PPP \$) waste intensity, \% to 2015 level

\begin{tabular}{|c|c|c|c|c|c|c|c|}
\hline \multirow{2}{*}{2015} & \multirow{2}{*}{2016} & \multirow{2}{*}{2017} & \multirow{2}{*}{2018} & \multirow{2}{*}{2019} & \multicolumn{3}{|c|}{ benchmarks } \\
\cline { 6 - 8 } & & & & & 2020 & 2025 & 2030 \\
\hline 100.0 & 92.5 & 111.6 & 104.0 & 126.2 & 90.0 & 80.0 & 60.0 \\
\hline
\end{tabular}

A negative dynamic compared to 2015 is observed for the GDP waste intensity national sub-indicator. The volume of waste generated by all economic activities per unit of GDP increases from $977.4 \mathrm{~kg}$ per $2011 \mathrm{PPP} 1000$ USD in 2015 to 1233.5 in 2019. The target value for 2020 will most likely not be achieved.

\section{An assessment of the waste intensity of regional economies of Ukraine}

Gross regional product (GRP) waste intensity is proposed to evaluate using the same approach adopted at the national level with some modifications. GDP and GRP values are taken 
at constant 2015 prices (UAH) in this assessment by recalculating with the utilization of indexdeflator values (\% of the previous year) for 2016-2019 data years [2]. Regional consumer price indices (\% of the previous year) also may be used for the obtainment of GRP values at constant 2015 prices though index-deflator values characterize sectors of the economy more comprehensively and integrated.

Waste generation is considered from the economic activity of enterprises and organizations, excluding households [3] (data exclude the temporarily occupied territory of the Autonomous Republic of Crimea, the city of Sevastopol, and a part of temporarily occupied territories in the Donetsk and Luhansk regions). Values of GDP and GRP waste intensity are presented in Table 2 for constant 2015 prices.

Table 2

GRP waste intensity, $\mathrm{kg}$ per thsd UAH

\begin{tabular}{|c|c|c|c|c|c|}
\hline & 2015 & 2016 & 2017 & 2018 & 2019 \\
\hline Ukraine (GDP waste intensity) & 154.0 & 142.1 & 172.6 & 160.7 & 195.5 \\
\hline Autonomous Republic of Crimea & $\mathrm{n} / \mathrm{a}$ & $\mathrm{n} / \mathrm{a}$ & $\mathrm{n} / \mathrm{a}$ & $\mathrm{n} / \mathrm{a}$ & $\mathrm{n} / \mathrm{a}$ \\
\hline \multicolumn{6}{|l|}{ oblasts } \\
\hline Vinnytsya & 30.3 & 28.3 & 34.1 & 24.2 & 35.3 \\
\hline Volyn & 11.9 & 13.3 & 11.5 & 11.8 & 12.7 \\
\hline Dnipropetrovsk & 1053.3 & 983.0 & 1104.5 & 1085.5 & 1149.8 \\
\hline Donetsk & 145.2 & 170.0 & 191.3 & 205.4 & 227.3 \\
\hline Zhytomyr & 11.1 & 10.9 & 10.0 & 8.1 & 8.1 \\
\hline Zakarpattya & 1.1 & 2.0 & 1.3 & 1.5 & 0.8 \\
\hline Zaporizhzhya & 58.3 & 53.6 & 53.6 & 56.8 & 58.0 \\
\hline Ivano-Frankivsk & 42.8 & 41.5 & 41.1 & 38.8 & 59.1 \\
\hline Kyiv & 12.8 & 10.1 & 5.4 & 6.2 & 7.8 \\
\hline Kirovohrad & 863.2 & 872.0 & 1010.9 & 966.0 & 910.3 \\
\hline Luhansk & 103.2 & 88.7 & 26.1 & 21.7 & 15.5 \\
\hline Lviv & 28.5 & 26.0 & 22.4 & 18.7 & 15.4 \\
\hline Mykolayiv & 42.7 & 43.6 & 44.9 & 47.2 & 42.0 \\
\hline Odesa & 2.0 & 2.1 & 3.1 & 3.1 & 2.2 \\
\hline Poltava & 44.2 & 52.7 & 330.9 & 185.8 & 927.1 \\
\hline Rivne & 20.4 & 18.3 & 10.9 & 10.7 & 10.5 \\
\hline Sumy & 18.3 & 15.2 & 12.8 & 19.5 & 16.9 \\
\hline Ternopil & 27.4 & 29.3 & 62.6 & 50.2 & 30.3 \\
\hline Kharkiv & 7.7 & 9.0 & 8.0 & 7.5 & 7.5 \\
\hline Kherson & 12.1 & 10.7 & 11.0 & 10.7 & 9.8 \\
\hline Khmelnytskiy & 19.2 & 27.2 & 17.5 & 16.0 & 16.5 \\
\hline Cherkasy & 22.3 & 23.5 & 24.6 & 23.6 & 19.6 \\
\hline Chernivtsi & 15.0 & 14.7 & 12.2 & 9.0 & 8.7 \\
\hline Chernihiv & 15.1 & 13.7 & 13.7 & 12.2 & 11.2 \\
\hline \multicolumn{6}{|l|}{ cities } \\
\hline Kyiv & 1.2 & 1.1 & 0.8 & 0.7 & 0.7 \\
\hline Sevastopol & $\mathrm{n} / \mathrm{a}$ & $\mathrm{n} / \mathrm{a}$ & $\mathrm{n} / \mathrm{a}$ & $\mathrm{n} / \mathrm{a}$ & $\mathrm{n} / \mathrm{a}$ \\
\hline
\end{tabular}


GRP waste intensity outsiders are Dnipropetrovsk, Kirovohrad, and Poltava oblasts. Kyiv city, Zakarpattya and Odesa oblasts are leaders by the sub-indicator values. The 2019 ratio of GRP waste intensity is about 1500:1 for the Dnipropetrovsk and Zakarpattya oblasts. Obtained GRP waste intensity sub-indicator values show different dynamics at the regional level (Table 3).

Table 3

GRP waste intensity compared to $2015, \%$

\begin{tabular}{|c|c|c|c|c|c|}
\hline & 2015 & 2016 & 2017 & 2018 & 2019 \\
\hline Ukraine (GDP waste intensity) & 100.0 & 92.3 & 112.1 & 104.4 & 126.9 \\
\hline Autonomous Republic of Crimea & $\mathrm{n} / \mathrm{a}$ & $\mathrm{n} / \mathrm{a}$ & $\mathrm{n} / \mathrm{a}$ & $\mathrm{n} / \mathrm{a}$ & $\mathrm{n} / \mathrm{a}$ \\
\hline \multicolumn{6}{|l|}{ oblasts } \\
\hline Vinnytsya & 100.0 & 93.4 & 112.6 & 79.7 & 116.4 \\
\hline Volyn & 100.0 & 111.7 & 97.1 & 99.2 & 107.3 \\
\hline Dnipropetrovsk & 100.0 & 93.3 & 104.9 & 103.1 & 109.2 \\
\hline Donetsk & 100.0 & 117.1 & 131.8 & 141.5 & 156.6 \\
\hline Zhytomyr & 100.0 & 98.2 & 90.4 & 73.5 & 72.6 \\
\hline Zakarpattya & 100.0 & 181.7 & 117.9 & 136.6 & 70.0 \\
\hline Zaporizhzhya & 100.0 & 91.9 & 91.9 & 97.4 & 99.4 \\
\hline Ivano-Frankivsk & 100.0 & 97.0 & 96.0 & 90.7 & 138.2 \\
\hline Kyiv & 100.0 & 78.8 & 42.0 & 47.9 & 60.4 \\
\hline Kirovohrad & 100.0 & 101.0 & 117.1 & 111.9 & 105.5 \\
\hline Luhansk & 100.0 & 85.9 & 25.3 & 21.1 & 15.0 \\
\hline Lviv & 100.0 & 91.0 & 78.5 & 65.7 & 54.1 \\
\hline Mykolayiv & 100.0 & 102.2 & 105.2 & 110.7 & 98.5 \\
\hline Odesa & 100.0 & 106.0 & 153.8 & 150.7 & 107.0 \\
\hline Poltava & 100.0 & 119.3 & 749.3 & 420.9 & 2099.7 \\
\hline Rivne & 100.0 & 89.8 & 53.4 & 52.5 & 51.4 \\
\hline Sumy & 100.0 & 83.3 & 70.3 & 106.9 & 92.4 \\
\hline Ternopil & 100.0 & 106.9 & 228.5 & 183.2 & 110.5 \\
\hline Kharkiv & 100.0 & 116.0 & 103.4 & 97.1 & 96.5 \\
\hline Kherson & 100.0 & 88.7 & 90.6 & 88.6 & 80.7 \\
\hline Khmelnytskiy & 100.0 & 141.5 & 91.2 & 83.1 & 85.6 \\
\hline Cherkasy & 100.0 & 105.4 & 110.4 & 105.8 & 88.0 \\
\hline Chernivtsi & 100.0 & 97.9 & 81.2 & 60.4 & 57.9 \\
\hline Chernihiv & 100.0 & 90.7 & 90.6 & 81.1 & 74.1 \\
\hline \multicolumn{6}{|l|}{ cities } \\
\hline Kyiv & 100.0 & 88.1 & 68.6 & 57.7 & 54.3 \\
\hline Sevastopol & $\mathrm{n} / \mathrm{a}$ & $\mathrm{n} / \mathrm{a}$ & $\mathrm{n} / \mathrm{a}$ & $\mathrm{n} / \mathrm{a}$ & $\mathrm{n} / \mathrm{a}$ \\
\hline
\end{tabular}

Zhytomyr, Kyiv, Luhansk, Lviv, Rivne, Kharkiv, Kherson, Khmelnytskiy, Chernivtsi, and Chernihiv oblasts and the City of Kyiv demonstrate a more or less stable decrease in GRP waste intensity. It should be noticed that Luhansk, Lviv, Rivne, Kyiv, and Chernivtsi oblasts and Kyiv already achieved the 2030 national benchmark of $60.0 \%$ for GRP waste intensity sub-indicator. Extremely high values of the sub-indicator for Poltava oblast result from inclusion in the data set 
wastes produced in the process of stripping works when creating mines and careers by LLC "Yerystivskuy mining and processing plant" (2017, 2018 years) and wastes produced in the process of mining and enrichment of iron ore PJSC "Poltava Mining and Processing Plant" (2019 year). The number of reporting enterprises on the volume of waste generation, accuracy and completeness of the data decreased in Donetsk and Luhansk oblasts that also must be taken into account. The obtained results represent the progress made towards the achievement of the nationally determined target of the economic dimension's SDG 12 on the regional level. There are a lot of explicit and hidden factors that affect such variations, mainly the peculiarities of regions' economies.

Values of GRP carbon intensity and GRP water intensity, or other components of resource intensity of GRP, can be evaluated using this comparability approach [4]. These assessments can be implemented as part of SDGs indicators framework at the regional level or become a part of integrated assessments as, for example, metric for sustainable development processes measurement for the regions of Ukraine [5] based on indicators of the quality and security of life components of the sustainable development index (SDI). The SDI quality of life component is an integration of three dimensions of sustainable development, economic, environmental, and social, and based on three pillars' sustainability model. Here GRP resource intensity indicator components can be used for regional level assessment in contexts of environmental management.

\section{Conclusion}

GRP waste intensity assessment is presented for 2015-2019 data years based on GRP values at constant 2015 prices and waste generation by regions from the economic activity of enterprises and organizations. GRP waste intensity sub-indicator values for regions of Ukraine are presented compared to the 2015 base year considering the SDG 12 benchmarks. Best performers in GRP waste intensity decreasing among the regions of Ukraine are identified for the 2019 year namely Luhansk, Lviv, Rivne, Kyiv, and Chernivtsi oblasts and the City of Kyiv.

\section{References}

[1] The Voluntary National Review of the SDGs achievement progress 2020 Report. The Department of Economic Strategy and Macroeconomic Forecasting of the MDETA. (2020). Retrieved from https://sustainabledevelopment.un.org/content/documents/ 26295VNR_2020_Ukraine_Report.pdf

[2] Gross regional product (2004-2019). State Statistics Service of Ukraine. (2020). Retrieved from http://www.ukrstat.gov.ua/operativ/operativ2020/vvp/vrp/vrp2019_ue.xls

[3] Environment of Ukraine. State Statistics Service of Ukraine. (2020). Statistical yearbook. Retrieved from http://www.ukrstat.gov.ua/druk/publicat/kat_u/2020/zb/11/Dovk_19.xlsx

[4] Dzhygyrey I. (2020). Ocinka skladnykiv resursoyemnosti VRP dlya analizu stalogo rozvytku regioniv Ukrayiny. 3-a MNPK "Ekologichni problemy navkolyshnogo seredovyshha ta racionalnogo pryrodokorystuvannya v konteksti stalogo rozvytku". 22-23 zhovtnya 2020 r. Kherson. 199-202.

[5] Sustainable Development Analysis: Global and Regional Contexts. International Council for Science (ICSU) and others; Scientific Supervisor of the Project M. Zgurovsky. Igor Sikorsky KPI. Part 2. Ukraine in Sustainable Development Indicators (2016-2017). 72 p. (2017). Retrieved from http://wdc.org.ua/sites/default/files/SD2017-P2-FULL-EN.pdf 